\title{
Zooplankton, zooplanktivorous fish and their interactions in Southeast Asian waterbodies with special reference to Sri Lanka: a review
}

\author{
Jacobus Vijverberg \\ the Netherlands \\ Correspondence (k_vijverberg@yahoo.co.uk) \\ (iD) https://orcid.org/0000-0003-2791-3646
}

Netherlands Institute of Ecology (NIOO-KNAW), Droevendaalsesteeg 10, 6708 PB Wageningen,

\begin{abstract}
Many countries in Southeast Asia have no natural lakes but reservoirs, flood-plains and rivers. The reservoirs are mainly inhabited by riverine fish species and introduced pelagic exotics. Benthivores, herbivores and detritivores dominate, whereas zooplanktivores are relatively rare (generally $4.6-9.5 \%$ of the fish community). Therefore, zooplanktivorours fish are not dominant in most Sri Lankan reservoirs and play only a minor role in the food web. In the Southeast Asian region, only small, often pelagic, zooplanktivorous fish species occur. They are either of riverine or marine origin. Observations were made that only six predominantly zooplanktivorous species viz a cyprinid from riverine origin Rasbora daniconius, a half beak from marine origin Hemiramphus limbatus, the glass perchlet Ambassis urotaenia and three freshwater clupeids from marine origin (Clupeichthys aesarnensis, Ehirava fluviatilis, Sardinella tawilis) inhabit the reservoirs in Southeast Asian countries such as Sri Lanka and Thailand and a lake in the Philippines. The highest percentages of zooplanktivory in the tropical region are observed in waterbodies which contain zooplanktivores of marine origin. These small pelagics are very productive, i.e., have relative high Annual Production/Biomass (P/B) ratios. P/B ratios of the small Southeast Asian pelagics ranged generally from 3-6, small clupeids showed the highest $\mathrm{P} / \mathrm{B}$ ratios. Of the riverine species, $R$. daniconius is the most successful; it is a common species in the Sri Lankan reservoirs. This species is, however, not able to catch the small cladocerans and the cyclopoid copepods efficiently and fails completely to catch the fast moving calanoid copepods. Instead of feeding on larger zooplankton, they often feed on adult winged midges which are floating on the water surface. H. limbatus is not abundant in Sri Lankan reservoirs and its distribution is limited where only occasionally its densities are high enough to permit a profitable fisheries. Although the freshwater clupeids seem to be superior in their efficiency of collecting food organisms, their distribution is often limited. Despite their ability to build up stable and large populations in a handful of water bodies in the Philippines and Sri Lanka, they have a problem in dispersing into other freshwater lakes and reservoirs. In Thailand, the situation is different because $C$. aesarnensis is well adapted to riverine conditions and, therefore, present in all reservoirs with inflowing riverine habitats, but in most cases these stocks are still unexploited.
\end{abstract}

Keywords: fish species of marine origin, fish species of riverine origin, freshwater clupeids, zooplankton body-size

\section{INTRODUCTION}

In the tropical waterbodies, the body size of zooplankton is generally smaller than those in cold water lakes and large zooplankton such as Daphnia spp. are scarce or lacking. Reduced zooplankton body size in warm waters can be generally attributed to small species replacing larger ones. It is therefore important to understand how size composition of zooplankton is structured in tropical water bodies in relation to predation by zooplanktovorous fish. It must be noted that in the tropics, large zooplanktivorous fish are not found, only small pelagics, small zooplanktivorous fish species which inhabit the pelagic zones (open water) of reservoirs and lakes. The present paper reviews zooplankton, zooplanktivorous fish and their interactions in eight waterbodies in three in Southeast Asian countries, Sri Lanka, Thailand and the Philippines. The review is based mainly on three sources of information: (1) results from the Austrian-English-Sri Lankan ecosystem study of Parakrama Samudra reservoir carried out from 1979-1982; (2) the results from The Netherlands-Sri Lankan fish and zooplankton studies on Tissawewa reservoir carried out from 1989-1992; and (3) the results from the FISHSTRAT project (1998-2002), a project supported by the European Union which was aimed to develop strategies for partitioning the productivity of Asian reservoirs and lakes between capture fisheries and aquaculture (Amarasinghe et al. 2001). Within the framework of the FISHSTRAT 


\section{J. Vijverberg}

project, three Sri Lankan reservoirs (Minneriya, Udawalawe, Victoria), one Thai reservoir (Ubolratana) and one crater lake in the Philippines (Lake Taal) were studied.

\section{ZOOPLANKTON}

\section{General}

Water temperature is one of the most important abiotic factors in aquatic systems because of its effect on the growth and survival of aquatic organisms (Hoekman 2010; Beveridge et al. 2010; Schriever 2015). As the tropical regions receive high annual irradiance and show low daily and annual variations in irradiance, tropical lakes and reservoirs have generally higher water temperatures and show a lower seasonal variation in water temperature than in temperate waterbodies (Lewis 1987).

Body size of zooplankton is a highly important attribute because of the influence it has on bioenergetics in aquatic food webs. Body size affects the manner in which the zooplankton interacts with its resources. Large-bodied zooplankton have higher grazing rates, having ability to graze a wider size range of food items, and therefore have greater top-down effects on resources than small-bodied zooplankton (Carpenter and Kitchell 1988). Likewise body size affects the availability and anti-predator responses of zooplankton to both invertebrate and vertebrate predators (Zaret 1980; Gélinas et al. 2007).

In the temperate region, the relatively large Daphnia spp. are a key element in the functioning of many freshwater ecosystems. They often control the algal growth via predation and guarantee the survival of the youngest stages of most freshwater fish species. Further they sustains the pelagic fish production relying on zooplanktivores as realised by obligatory zooplanktivores, facultative zooplanktivores and of piscivores (Lazzaro 1987).

In the tropical warm water lakes and reservoirs, the body size of zooplankton is generally smaller than of those in cold water lakes and Daphnia spp. are scarce or lacking (e.g. Fernando 1980; Amarasinghe et al. 1997; Gillooly and Dodson 2000; Havens et al. 2014). This is generally true for cladocerans and cyclopoid copepods, but not for calanoid copepods (Havens et al. 2014).
Although reduced zooplankton body size in warm waters can be generally attributed to small species replacing larger ones (Gillooly and Dodson 2000; Havens et al. 2014), the reason for the smaller body size in the tropical region is at present not clear. It may be due to that large-bodied zooplankton has a lower upper thermal tolerance (Moore et al. 1996), or that large-bodied zooplankton is stronger effected by low oxygen availability mediated by high and uniform temperatures (Chapelle and Peck 1999), or that large-bodied zooplankton is more vulnerable to food limitation (Lehman 1988), and/or that it is a response to the positive size selective predation of the zooplanktivorous fish (Zaret1980), or a combination of all above.

\section{Zooplankton of Southeast Asian Region}

Common microcrustacean zooplankton species of Southeast Asian waterbodies are listed in Table 1. The species composition of copepods and cladocerans in Ubolratana and four Sri Lankan reservoirs was very similar, where the cyclopods were dominated by two species only: Mesocyclops thermocyclopoides and Thermocyclops decipiens. In all five reservoirs, calanoid copepods were dominated by a single species. In Sri Lankan reserviors this was Phyllodiaptomus annae while in Ubolratana it was Neodiaptomus botulifer. All the reservoirs shared many cladoceran species such as Bosminopsis dietersi, Ceriodaphnia cornuta, Moina micrura, Diaphanosoma excisum and D. modigliani. There were two exceptions, D. sarsi was not found in Ubolratana reservoir and Daphnia lumholtzi was only common in one location at the Ubolratana reservoir. D. lumholtzi was also occasionally observed in the four Sri Lankan reservoirs but always in very low densities.

The zooplankton species composition of Lake Taal was different in several respects. The calanoid copepod species was different, and both cyclopoid species were different too. However, one of these species, Thermocyclops crassus is taxonomically closely related to Thermocyclops decipiens, which is common in the Sri Lankan and Thai reservoirs. Of the cladocerans, Bosminopsis dietersi was not present in Lake Taal, but instead another species of the Bosminidae, Bosmina fatalis, was present. Of the Sididae, Di. excisum and Di. modigliani were lacking, but Di. sarsi was present. 


\section{Zooplankton in Sri Lankan reservoirs}

The zooplankton of five Sri Lankan reservoirs, Minneriya, Parakrama Samudra, Tissawewa, Udalawawe and Victoria, were investigated by Duncan (1983), Amarasinghe et al. (1997) and Amarasinghe et al. (2008) (Table 1). Although four of the reservoirs are located in the south-eastern lowlands and Victoria Reservoir in the Central Hill region, four of the five reservoirs have a similar zooplankton species composition (Table 1). The fifth reservoir, Parakrama Samudra, is a notable exception where it is the only Sri Lankan reservoir known to have a pelagic zooplankton community which lacks crustacean zooplankton and contains only rotifers (Duncan 1983). The zooplankton community of the four other reservoirs was generally composed of six cladoceran spp. Bosminopsis dieters, Ceriodaphnia cornuta, Moina micrura, Diaphanosoma excisum, Diaphanosoma modigliani, Diaphanosoma sarsi, two cyclopoid spp. Mesocyclops thermocyclopoides, Thermocyclops decipiens and one calanoid spp. Phyllodiaptomus annae.

Table 1 List of common microcrustacean zooplankton species in Southeast Asian waterbodies based on observations in Philippines (PH), Sri Lanka (SL) and Thailand (TH) according to A = Duncan (1983, 1999), B =Amarasinghe et al. (1997), C = Amarasinghe et al. (2008). Sampled waterbodies are: Minneriya (SL, MIN), Parakrama Samudra (SL, PS), Tissawewa (SL, TI), L. Taal (PH, TA), Ubolratana (TH, UB), Udalawawe (SL, UDA) and Victoria (SL, VI). Abbreviation used: $\mathrm{nm}=$ not measured.

\begin{tabular}{|c|c|c|c|c|c|}
\hline Species & $\begin{array}{l}\text { Taxonomic } \\
\text { group }\end{array}$ & $\begin{array}{l}\text { Max. } \\
\text { Length } \\
(\mathrm{mm})\end{array}$ & Country & Waterbody & Authority \\
\hline Heliodiaptoтиs viduиs & Calanoid cop. & $\mathrm{nm}$ & SL & TI & $\mathrm{B}$ \\
\hline Phyllodiaptomиs anпаe, & Calanoid cop & 1.3 & SL & 4 res. & $\mathrm{B}, \mathrm{C}$ \\
\hline Neodiaptomus botulifer & Calanoid cop & $\mathrm{nm}$ & $\mathrm{TH}$ & UB & $\mathrm{C}$ \\
\hline Tropodiaptomus vicinus & Calanoid cop. & $\mathrm{nm}$ & $\mathrm{PH}$ & TA & $\mathrm{C}$ \\
\hline Mesocyclops thermocyclopoides & Cyclopoid cop. & 1.0 & SL, TH & 5 res. & $\mathrm{B}, \mathrm{C}$ \\
\hline Microcylops varicans & Cyclopoid cop. & $\mathrm{nm}$ & $\mathrm{PH}$ & TA & $\mathrm{C}$ \\
\hline Thermocyclops decipiens & Cyclopoid cop & $\mathrm{nm}$ & SL, TH & 5 res. & $\mathrm{B}, \mathrm{C}$ \\
\hline Thermocyclops crassus & Cyclopoid cop & $\mathrm{nm}$ & $\mathrm{PH}$ & TA & $\mathrm{C}$ \\
\hline Bosminopsis dietersi & Cladocera & 0.4 & SL, TH & 4 res. & $\mathrm{C}$ \\
\hline Bosmina fatalis & Cladocera & 0.4 & $\mathrm{PH}$ & TA & $\mathrm{C}$ \\
\hline Ceriodaphnia cornuta & Cladocera & 0.7 & $\begin{array}{l}\text { SL, TH, } \\
\text { PH }\end{array}$ & 6 water-bodies & $\mathrm{B}, \mathrm{C}$ \\
\hline Daphnia lumholtzi & Cladocera & 1.5 & $\mathrm{TH}$ & UB & $\mathrm{C}$ \\
\hline Diaphanosoma excisum & Cladocera & 1.3 & SL, TH & 5 res. & $\mathrm{B}, \mathrm{C}$ \\
\hline Di. modigliani & Cladocera & 1.3 & SL, TH & 5 res. & $\mathrm{B}, \mathrm{C}$ \\
\hline Di. sarsi & Cladocera & 1.3 & SL, PH & 4 water-bodies. & $\mathrm{C}$ \\
\hline Moina micrura & Cladocera & 0.7 & $\begin{array}{l}\text { SL, TH, } \\
\text { PH }\end{array}$ & 6 water-bodies & $\mathrm{B}, \mathrm{C}$ \\
\hline Rotifers & Rotifera & 0.1 & SL & PS & A \\
\hline
\end{tabular}

\section{ZOOPLANKTIVOROUS FISH}

\section{General}

Herbivory in fish communities is more prevalent in the tropical region whereas carnivory is more common at higher latitudes (Floeter et al. 2005; Behrens and Lafferty 2007; Gonzalez-Bergonzoni et al. 2012). The possible explanatory mechanisms for the dominance of carnivores at lower temperatures is that because gut passage rate decreases more rapidly than metabolic rate as temperature declines, and that herbivorous fish may not be able to process enough food material to meet their metabolic demands at cooler temperatures (Floeter et al. 2005).

Recently, Boersma et al. (2015) proposed an alternative hypothesis to explain the dominance of herbivores at higher temperatures. They conclude that respiration rates increase more rapidly than growth rates as temperature increases and this 


\section{J. Vijverberg}

should result in higher demand for metabolic carbon at higher temperatures. Since algae and plant material contain a higher relative carbon content relative to $\mathrm{P}$ and $\mathrm{N}$ nutrients than animal food, algal food and plant material will become the preferred food at higher temperatures.

\section{Zooplanktivorous fish in Southeast Asian waterbodies}

The percentages of zooplanktivory in Sri Lankan fish communities was generally low, generally between 4.6 and $9.5 \%$ (Table 2). This is in contrast with temperate fish communities where the percentage of zooplanktivores is usually in the range of 40-90\% (Vijverberg et al. 2014). However, in some Southeast Asian waterbodies higher percentages of zooplanktivory were observed. These waterbodies had one characteristic in common, they contained successful clupeid populations. In Parakrama Samudra reservoir (17.7\% zooplanktivores) in Sri Lanka, Ubolratana reservoir (25\%) in Thailand and Lake Taal (59\%) in the Philippines were observed with successful clupeid populations (Table 2).

Table 2 Percentage zooplanktivory (\%, biomass) of six fish communities in Southeast Asian water bodies according to $\mathrm{A}=$ Sricharoendham et al. (2008), $\mathrm{B}=$ Vijverberg et al. (20014) and C = Villanueva et al. (2008), $\mathrm{PH}=$ Philippines, $\mathrm{SL}=$ Sri Lanka and $\mathrm{TH}=$ Thailand.

\begin{tabular}{lrcc}
\hline Water body & $\begin{array}{l}\text { Zooplankti- } \\
\text { vory }(\%)\end{array}$ & Country & Authority \\
\hline Minneriya & 5.8 & SL & B \\
Parakrama & 17.7 & SL & C \\
Samudra & & & \\
Lake Taal & 59 & PH & A \\
Tissawewa & 9.5 & SL & B \\
Ubolratana & 25 & TH & C \\
Victoria & 4.6 & SL & B \\
\hline
\end{tabular}

Small pelagics were studied in five reservoirs (Minneriya, Tissawewa, Udawalawe, Victoria, Ubolratana) and one natural lake (Lake Taal) by Pet et al. (1996) and Ariyaratne et al. (2008). The results are summarized in Table 3. Rasbora daniconius (Cyprinidae) was present in all four Sri Lankan reservoirs, whereas the half-beak Hyporhamphus limbatus (Hemiramphidae) was present in Minneriya, Tissa wewa and Udawalawe reservoir but not in Victoria reservoir. In Ubolratana reservoir
(Thailand), the clupeid Clupeichthys aesarnensis was a common fish species in terms of production and numbers. In Lake Taal (Philippines), two small pelagics were present, the endemic clupeid Sardinella tawilis and the glass perch Ambassis urotaenia (Ambassidae). S. tawilis is the dominant zooplanktivore in Lake Taal, whereas $R$. daniconius was common in three of the four Sri Lankan reservoirs (Minneriya, Tissawewa, Udawalawe). The small clupeid Ehirava fluviatilis was only successful in two Sri Lankan reservoirs (Mihindukulasooriya and Amarasinghe 2014). The glass perch $A$. urotaenia and the halfbeak, $H$. limbatus, were the least successful in the Asian waterbodies studied in terms of abundance.

In general small pelagics are very productive, i.e. have a relative high annual Production/Biomass $(\mathrm{P} / \mathrm{B})$ ratios, higher than larger fish species living under similar conditions (e.g. Dejen et al. 2009). The annual Production/Biomass (P/B) ratio is the accumulated production over 12 months divided by the average biomass over the same period. The P/B ratios of the small pelagics from Southeast Asia were usually in the range of 3-6. The small clupeids showed the highest production rates (Table 3 ).

\section{Zooplanktivorous fish in Sri Lankan reservoirs}

Sri Lanka, like most other countries in Southeast Asia, has no natural lakes but only reservoirs, floodplains and rivers. The reservoirs are mainly inhabited by riverine fish species and the introduced pelagic exotics (Oreochromis mossambicus and $O$. niloticus). Benthivores, herbivores and detritivores dominate, whereas zooplanktivores are relatively rare. The early life stages of all fish species feed upon zooplankton (Fernando 1994). However, because of their small size and short duration of this larval life stage, their share in the total zooplankton predation is likely to be insignificant. Three species of small zooplanktivorous pelagic fish were recorded, but only one species, the cyprinid $R$. daniconius exhibited a relatively high abundance with a wide distribution (De Silva and Sirisena 1987; Amarasinghe 1990; Pethiyagoda 1991; Wijeyaratne and Perera 2001) (Table 3). The halfbeak $H$. limbatusis of marine origin, occurs generally at low densities and has a limited distribution. 


\section{J. Vijverberg}

Table 3 List of zooplanktivorous fish observed in waterbodies in Philippines (PH), Sri Lanka (SL) and Thailand (TH) according to A= Newrkla and Duncan (1984), B = Pet et al. (1996), C= Ariyaratne et al. (2008). Fish length measuresd as total length (TL). Abbreviation used: $\mathrm{nm}=$ not measured.

\begin{tabular}{|c|c|c|c|c|c|c|}
\hline Species & Common name & Family & $\begin{array}{l}\text { Max } \\
\text { Length } \\
(\mathrm{TL}, \mathrm{cm})\end{array}$ & $\mathrm{P} / \mathrm{B}$ & $\begin{array}{l}\text { Waterbody, } \\
\text { Country }\end{array}$ & Authority \\
\hline $\begin{array}{l}\text { Ambassis urotaenia } \\
\text { Bleeker, } 1852\end{array}$ & $\begin{array}{l}\text { Banded-tail } \\
\text { glass perchlet }\end{array}$ & $\begin{array}{l}\text { Ambassi- } \\
\text { dae }\end{array}$ & 14.0 & $\mathrm{~nm}$ & $\begin{array}{l}\text { L. Taal } \\
\text { PH }\end{array}$ & $\mathrm{C}$ \\
\hline $\begin{array}{l}\text { Hyporhamphus limbatus } \\
\text { (Valenciennes, 1847) }\end{array}$ & Half-beak & $\begin{array}{l}\text { Hemiram- } \\
\text { phidae }\end{array}$ & 17.6 & 2.0 & $\begin{array}{l}3 \text { SL res- } \\
\text { ervoirs }\end{array}$ & $\mathrm{B}, \mathrm{C}$ \\
\hline $\begin{array}{l}\text { Rasbora daniconius } \\
\text { (Hamilton, 1822) }\end{array}$ & Slender Rasbora & Cyprinidae & 15.0 & 3.3 & $\begin{array}{l}4 \text { SL res- } \\
\text { ervoirs }\end{array}$ & $\mathrm{B}, \mathrm{C}$ \\
\hline $\begin{array}{l}\text { Sardinella tawilis } \\
\text { (Herre, 1927) }\end{array}$ & $\begin{array}{l}\text { Freshwater } \\
\text { Sardinella }\end{array}$ & Clupeidae & 13.5 & 5.0 & $\begin{array}{l}\text { L. Taal } \\
\text { PH }\end{array}$ & $\mathrm{C}$ \\
\hline $\begin{array}{l}\text { Clupeichthys aesarnensis } \\
\text { (Wongratana, 1983) }\end{array}$ & Thai river sprat & Clupeidae & 7.0 & 4.0 & $\begin{array}{l}\text { Ubolratana } \\
\text { res., TH }\end{array}$ & $\mathrm{C}$ \\
\hline $\begin{array}{l}\text { Ehirava fluviatilis } \\
\text { Deraniyagala, } 1929\end{array}$ & Malabar sprat & Clupeidae & 5.5 & 6.0 & $\begin{array}{l}\text { Parakrama } \\
\text { Samudra } \\
\text { res., SL }\end{array}$ & A \\
\hline
\end{tabular}

The small clupeid E. fluviatilis from marine origin, has a limited distribution. Parakrama Samudra reservoir, an ancient reservoir in the Mahaweli River basin supports high densities of $E$. fluviatilis and they are spawning within the reservoir (Newrkla and Duncan 1984). Only one other Sri Lankan freshwater body Rajanganaya reservoir in the Kala Oya River basin is known to be inhabited by E. fluviatilis (Amarasinghe and Sriya, 2002; Mihindukulasooriya and Amarasinghe 2014). This species has been reported in several river estuaries of Sri Lanka (Pethiyagoda 1991), but a traditional seasonal fishery is established only in Bolgoda Lake in the Panadura estuary (Amarasinghe and Sriya, 2002). This fishery with the annual yield of about. $23.2 \mathrm{~kg} \mathrm{ha}^{-1}$ is profitable and sustainable, but it is unlikely that spawning takes place within the estuary (Amarasinghe and Sriya 2002).The size range of the individuals in Parakrama Samudra reservoir and Bolgoda Lake was very similar, both having a maximum length (TL) of $5.5 \mathrm{~cm}$, but the two populations differ in several other life history parameters. Size at first maturity of this species is higher in the estuarine population ( $35 \mathrm{~mm}$ TL) than in the reservoir population ( $20 \mathrm{~mm} \mathrm{TL}$ ) and the body weight condition is much higher in the estuary (Newrkla and Duncan 1984; Amarasinghe and Sriya, 2002).

\section{Fish - zooplankton interactions in Southeast Asia}

Ariyaratne et al. (2008) tested the hypothesis that riverine cyprinid fishes (e.g., $R$. daniconius) feed less efficiently on zooplankton than species from marine origin, e.g. H. limbatus and the clupeids $C$. aesarnensis, E. fluviatilis and S. tawilis. This is based on the notion that at sea, microcrustacean zooplankton is common, but in rivers they are extremely scarce. As a result riverine fish in rivers and streams feed mainly on benthic food organisms and on insects, which are falling out of the trees. Therefore, fish from marine origin should be better adapted to feeding on zooplankton than riverine fish species, but riverine fish should be better adapted to feeding on adult insects. In the Sri Lankan reservoir, Parakrama Samudra, the clupeid E. fluviatilis was able to build up a sustainable population with a mean biomass of $60 \mathrm{~kg}$ fresh wt $\mathrm{ha}^{-1} \mathrm{yr}^{-1}$ by consuming exclusively on small rotifers (average size $0.05 \mathrm{~mm}$ ) (Duncan 1999).

Small pelagic species seem to be adapted to some degree to the available size distribution of food organisms. If very large food items were available, even at relatively low densities, the fish develop a strong positive selection for these food items. However, not all fish species were equally efficient. The clupeid, $C$. aesarnensis, was the most effective particulate feeder; they were very efficient in feeding on larger food items such as adult midges and even small fish (Table 4). The other clupeid, $S$. tawilis, was very efficient on large calanoid 


\section{J. Vijverberg}

copepods. This contrasts with $H$. limbatus and $R$. daniconius. Catching calanoid copepods is not an easy task because they are fast swimmers that can swim against water currents. Cyclopod copepods are slower swimmers than calanoids but faster than cladocerans. The fish catch prey by sucking them in one by one and therefore calanoid copepods, followed by cyclopod copepods have the best chances and cladocerans the poorest chances to escape fish predation (Drenner and McComas 1984).This shows that $S$. tawilis is a very efficient zooplankton feeder. In contrast, $H$. limbatus from coastal marine origin and the indigenous riverine $R$. daniconius, were mainly selecting slow or immobile prey. The medium and larger-sized cladocerans, which are slow swimmers, and the large adult insects which were floating on the surface are largely immobilized. Thus the fish species of riverine origin was indeed less efficient in feeding on fast moving zooplankton, but not all fish species of marine origin were efficient feeders on fast moving preys. Apparently only the clupeids are very efficient, both on relative large and on relative small preys and on fast moving large calanoid copepods (Table 4).

Table 4 Maximum prey size in the diets of zooplanktivorous fish observed in waterbodies in Philippines (PH), Sri Lanka (SL) and Thailand (TH) according A= Duncan (1999) and B= Ariyaratne et al. (2008). Prey types are indicated: $\mathrm{ZOO}=$ microcrustacean zooplankton, $\mathrm{RO}=$ rotifers, $\mathrm{MA}=$ macrofauna, $\mathrm{FISH}=$ fish.

\begin{tabular}{lllll}
\hline Species & $\begin{array}{l}\text { Maximum Prey } \\
\text { Length }(\mathrm{mm})\end{array}$ & Prey type & $\begin{array}{l}\text { Waterbody, } \\
\text { Country }\end{array}$ & Authority \\
\hline Ambassis urotaenia & 1.2 & ZOO & L. Taal, PH & $\mathrm{B}$ \\
Hyporhamphus limbatus & 1.0 & ZOO & 3 SL res. & $\mathrm{B}$ \\
& 6.5 & $\mathrm{MA}$ & 3 SL res. & $\mathrm{B}$ \\
Rasbora daniconius & 1.0 & ZOO & 3 SL res & $\mathrm{B}$ \\
& 6.0 & $\mathrm{MA}$ & 3 SL res & $\mathrm{B}$ \\
Sardinella tawilis & 7.5 & $\mathrm{MA}$ & 3 SL res & $\mathrm{B}$ \\
Clupeichthys aesarnensis & 1.2 & ZOO & L. Taal, PH & $\mathrm{B}$ \\
& 1.3 & ZOO & Ubolratana res., TH & $\mathrm{B}$ \\
& 1.8 & MA & Ubolratana res., TH & $\mathrm{B}$ \\
Ehirava fluviatilis & 10.0 & FISH & Ubolratana res., TH & $\mathrm{B}$ \\
\hline
\end{tabular}

Fish - zooplankton interactions in Sri Lankan reservoirs

$R$. daniconius and $H$. limbatus generally selected the larger cladoceran species (e.g. Diaphanosoma spp., Daphnia lumholzi) and the, a medium-sized Moina micrura, whereas small cladoceran species (e.g. Bosminopsis dietersi, Ceriodaphnia cornuta) and copepods were negatively selected or avoided (Ariyaratne et al. 2008). On a numerical basis, $R$. daniconius and $H$. limbatus are mainly zooplanktivorous, feeding on large proportions of cladocerans. But, if we compare the diet composition on the basis of biomass, than $R$. daniconius mainly feeds on adult flying insects, whereas $H$. limbatus also consumed a fair proportion of adult insects. The adult insects were probably eaten when floating at the water surface or in the upper water layers. On the basis of biomass, the contribution of insects in the total diet was high for
$R$. daniconius (ca. $65 \%$ ) and for H. limbatus (ca. $40 \%$ ).

In Parakrama Samudra reservoir the clupeid $E$. fluviatilis was feeding on small rotifers whereas in Bolgoda Lake in the Panadura estuary this species was feeding mainly on larger copepods (range: 0.6$1.3 \mathrm{~mm}$ ). This apparently resulted in a much better body condition of the species in the estuary as compared with the reservoir (Newrkla and Duncan 1984; Amarasinghe and Sriya 2002).

\section{Success of small pelagic freshwater clupeids}

The small freshwater clupeid species are flexible and opportunistic feeders, which feed very efficiently on a whole range of food organisms from very small (ca. $0.05 \mathrm{~mm}$ ) up to relatively large (up to $10 \mathrm{~mm}$ ) ones and range from slow moving species to fast moving species (Duncan 1999; Ariyaratne et al. 2008). It is therefore expected that clupeids 


\section{J. Vijverberg}

would be always more successful in terms of abundance than fish species from riverine origin. However, this is not always the case.

Clupeids are not successful in Sri Lankan reservoirs. The facultative freshwater clupeid, $E$. fluviatilis, mainly inhabits coastal marine habitats and estuaries (Pethiyagoda 1991) and is found only in two Sri Lankan reservoirs, both well connected by a river to the sea, Parakrama Samudra and Rajanganaya reservoirs (Newrkla and Duncan, 1984; Amarasinghe and Sriya 2002). E. fluviatilis is however, able to build up a stable and abundant locally reproducing population in Parakrama Samudra (Newrkla and Duncan 1984; Ariyaratne et al. 2008), which is a pure freshwater reservoir. Hence, after colonising a particular reservoir they may be quite successful. However, in comparison with an estuarine population mainly feeding on large copepods, the individuals belonging to the enclosed freshwater population mature at a smaller size and have a poorer body condition (Amarasinghe and Sriya 2002). This suggests that food conditions are comparatively poor in the freshwater reservoir. Apparently, small food items such as rotifers are not so profitable as larger microcrustacean zooplankton items such as copepods (Duncan 1983, 1999; Amarasinghe and Sriya 2002).

In Thailand, commercial fish catches show that in only three of the twelve reservoirs the freshwater clupeid $C$. aesarnensis yields are substantially contributing to the total fish catch, i.e. Sirindhorn $(65 \%)$, Sirikit (30\%), Ubolratana (15\% of total catch) (EGAT 1991). However, C. aesarnensis, although from marine origin has adapted itself to riverine conditions and is generally present in all major river systems in Thailand. Since local markets are often not available for $C$. aesarnensis, this species is not exploited in most reservoirs. This is probably the reason why this fish species was only reported from a few reservoirs. This clupeid species has most likely a more general distribution than what appears from the published records.

In Lake Taal, there was until recent times a very successful fishery on S. tawilis (annual catch $440 \mathrm{~kg}$ $\mathrm{ha}^{-1} \mathrm{yr}^{-1}$, relative yield 79\%) (Baluyut 1999). This species is certainly successful in Lake Taal, but is absent in other Philippine waterbodies.

In conclusion, freshwater clupeids are not successful in the Philippines (one lake only), and neither in Sri Lanka (only 2 reservoirs), but they are successful in Thailand where they inhabit all major river systems and probably most reservoirs linked to the river systems.

\section{ACKNOWLEDGEMENTS}

I thank Professor Upali S. Amarasinghe (Department of Zoology and Environmental Management, University of Kelaniya) for valuable comments on earlier drafts of the manuscript. The research was supported by contract no. ERB 3514 PL 961695 of the European Commission's INCODC Programme. The study in Sri Lanka by Dr. Bandu Amarasinghe and Mr. M.G. Ariyaratne on the zooplankton ecology and ecology of small zooplanktivorous fish was supported by the Vijverhof Fund (The Netherlands) and the SchureBeijerinck-Popping Fund of the KNAW (The Netherlands). This is the publication no. 6488 of The Netherlands Institute of Ecology (NIOO-KNAW)

\section{REFERENCES}

Amarasinghe P.B., J. Vijverberg and M. Boersma 1997. Production biology of copepods and cladocerans in three south-east Sri Lankan lowland reservoirs and its comparison to other tropical waterbodies. Hydrobiologia 350: 145162. https://doi.org/10.1023/A:1003035831790

Amarasinghe P.B., M.G. Ariyaratne, T. Chittapalapong and J. Vijverberg 2008. Production, biomass and productivity of copepods and cladocerans in South-East Asian waterbodies and the carrying capacity for zooplanktivorous fish. Chapter 9, 173-194 pp. In: Schiemer F., D. Simon, U.S. Amarasinghe and J. Moreau (eds), Aquatic Ecosystems and Development: Comparative Asian Perspectives. Margraf Publishers and Backhuys Publishers, Germany, Netherlands. 512 pp

Amarasinghe, U.S. 1990. Minor cyprinid resources in a man-made lake in Sri Lanka: a potential supplementary source of income for fishermen. Fisheries Research 9: 81-89.

Amarasinghe, U.S., A. Duncan, J. Moreau, F. Schiemer, D. Simon and J. Vijverberg 2001. Promotion of sustainable capture fisheries and aquaculture in Asian reservoirs and lakes. Hydrobiologia 458: 181-190.

https://doi.org/10.1023/A:1013181522746

Amarasinghe, U.S. and I.D.P. Sriya 2002. Aspects of the biology and fishery of Malabar Sprat, 


\section{J. Vijverberg}

Ehirava fluviatilis (Osteichthyes: Clupeidae) in Bolgoda Lake, Sri Lanka. Asian Fisheries Science 15: 215-228.

Ariyaratne, M.G., P.B. Amarasinghe, N.C. Lopez, M. Kakkaew and J. Vijverberg 2008. Selective feeding of small zooplanktivorous pelagic fish species in South-east Asian reservoirs (Sri Lanka, Thailand) and Lake Taal (Philippines). Chapter 13, 235-248 pp. In: Schiemer F., D. Simon, U.S. Amarasinghe and J. Moreau (eds), Aquatic Ecosystems and Development: Comparative Asian Perspectives. Margraf Publishers and Backhuys Publishers, Germany, Netherlands, 512 pp.

Baluyut, E.A. 1999. Introduction and fish stocking in lakes and reservoirs in Southeast Asia: a review. 117-141 pp. In: van Densen, W.L.T. and M.J. Morris (eds), Fish and fisheries of lakes and reservoirs in Southeast Asia and Africa, Westbury Publishing, Otley, UK.

Behrens, M. D. and K. D. Lafferty 2007. Temperature and diet effects on omnivorous fish performance: implications for the latitudinal diversity gradient in herbivorous fishes. Canadian Journal of Fisheries and Aquatic Sciences 64: 867-873. https://doi.org/10.1139/f07-063

Beveridge, O.S., S. Humphries and O. L. Petchey 2010. The interacting effects of temperature and food chain length on trophic abundance and ecosystem function. Journal of Animal Ecology 79: 693-700.

DOI: 10.1111/j.1365-2656.2010.01662.x

Boersma, M., K.A. Mathew, B. Niehoff, K.L. Schoo, R.M. Franco-Santos and C.L. Meunier 2015. Temperature driven changes in the diet preference of omnivorous copepods: no more meat when it's hot? Ecology Letters 19(1): 4553. DOI: $10.1111 /$ ele. 12541

Carpenter, S.R. and J.F. Kitchell 1988. Consumer control of lake productivity. Bioscience 38: 764769. https://doi.org/10.2307/1310785

Chapelle G., L.S. Peck 1999. Polar gigantism dictated by oxygen availability. Nature 399: 114115. DOI: $10.1038 / 20099$

De Silva, S.S. and H.K.G. Sirisena 1987. New fish resources of reservoirs in Sri Lanka: Feasibility of introduction of a subsidiary gillnet fishery for minor cyprinids. Fisheries Research 6: 17-34. DOI: 10.1016/0165-7836(87)90004-X
Dejen, E, J. Vijverberg, L.A.J. Nagelkerke and F.A. Sibbing 2009. Growth, biomass, and production of two small barbs (Barbus humilis and $B$. tanapelagius, Cyprinidae) and their role in the food web of Lake Tana (Ethiopia). Hydrobiologia 636: 89-100. https://doi.org/10.1007/s10750-009-9939-x

Drenner, R.W. and S.R. McComas 1984. The role of zooplankter escape ability and fish size selectivity in the selective feeding and impact of planktivorous fish. 587-593 pp. In: F.B. Taub (ed.), Lakes and reservoirs, Ecosystems of the world, Elsevier, Amsterdam, The Netherlands.

Duncan, A. 1983. The composition, density and distribution of the zooplankton in Parakrama Samudra. 87-94 pp. In: F. Schiemer (ed.), Limnology of Parakrama Samudra - Sri Lanka. Dr. W. Junk Publishers, The Hague.

Duncan, A. 1999. Pelagic fish and fisheries in Asian and African lakes and reservoirs. 347-382 pp. In: van Densen, W.L.T. and M.J. Morris (eds), Fish and fisheries of lakes and reservoirs in Southeast Asia and Africa, Westbury Publishing, Otley, UK.

EGAT 1991. Fisheries statistical report of EGAT reservoirs, for fiscal year 1990 (in Thai). Chemical and Analysis Department, Electricity Generating Authority of Thailand, Bangkok. 26 pp.

Fernando, C.H. 1980. The species and size composition of tropical freshwater zooplankton with special reference to the oriental region (South East Asia). Internationale Revue der gesamten Hydrobiologie 65: 411-426.

DOI: 10.1002/iroh.19800650310

Fernando, C.H. 1994. Zooplankton, fish and fisheries in tropical fresh waters. Hydrobiologia 272: $105-123$. https://doi.org/10.1007/BF00006516

Gélinas, M., B. Pinel-Alloul and M. Ślusarczyk 2007. Formation of morphological defences in response to YOY perch and invertebrate predation in two Daphnia species coexisting in a mesotrophic lake. Hydrobiologia 594: 175-185. DOI: $10.1007 / \mathrm{s} 10750-007-9078-1$

Gonzalez-Bergonzoni, I., M. Meerhoff, T. A. Davidson, F. Teixeira-de Mello, A. BaattrupPedersen and E. Jeppesen 2012. Meta-analysis shows a consistent and strong latitudinal pattern in fish omnivory across ecosystems. Ecosystems 15: 492-503. DOI: 10.1007/s10021-012-9524-4 


\section{J. Vijverberg}

Floeter, S.R., M.D. Behrens, C.E.L. Ferreira, M.J. Paddack and M.H. Horn 2005. Geographical gradients of marine herbivorous fishes: patterns and processes. Marine Biology 147: 1435-1447. DOI: $10.1007 / \mathrm{s} 00227-005-0027-0$

Gillooly, J.F. and S.I. Dodson 2000. Latitudinal patterns in the size distribution and seasonal dynamics of new world, freshwater cladocerans. Limnology and Oceanography 45: 22-30. DOI: $10.4319 /$ lo.2000.45.1.0022

Havens, K.E., R.M. Pinto-Coelho, M. Beklioğlu, K.S. Christoffersen, E. Jeppesen, T.L. Lauridsen, A. Mazumder, G. Méthot, B. PinelAlloul, U.N. Tavşanoğlu, Ş. Erdoğan and J. Vijverberg 2014. Temperature effects on body size of freshwater crustacean zooplankton from Greenland to the tropics. Hydrobiologia 743: 27-35. DOI 10.1007/s10750-014-2000-8.

Hoekman, D. 2010. Turning up the heat: Temperature influences the relative importance of top-down and bottom-up effects. Ecology 91: 2819-2825. DOI: $10.1890 / 10-0260.1$

Lazzaro, X. 1987. A review of planktivorous fishes: Their evolution, feeding behaviours, selectivities, and impacts. Hydrobiologia 146: 97-167. https://doi.org/10.1007/BF00008764

Lehman, J.T. 1988. Ecological principles affecting community structure and secondary production by zooplankton in marine and freshwater environments. Limnology and Oceanography 33: 931-945.

DOI: 10.4319/lo.1988.33.4part2.0931

Lewis, W.M. Jr. 1987. Tropical limnology. Annual Review of Ecology and Systematics 18: 159-184. https://doi.org/10.1146/annurev.es.18.110187.0 01111

Mihindukulasooriya, I.D. and U.S. Amarasinghe 2014. Food and feeding of Ehirava fluviatilis (Osteichthyes, Clupeidae) in Rajanganaya Reservoir, Sri Lanka. Sri Lanka Journal of Aquatic Sciences 19: 31-39.

http://doi.org/10.4038/sljas.v19i0.7449

Moore, M.V., C.F. Folt and R.S. Stemberger 1996. Consequences of elevated temperatures for zooplankton assemblages in temperate lakes. Archiv für Hydrobiologie 135: 289-319.

Newrkla, P. and A. Duncan 1984. The biology and density of Ehirava fluviatilis (clupeiod) in Parakrama Samudra, Sri Lanka. Verhandlungen der internationale Vereinigung für Limnologie 22: $1572-1578$.
Pet, J.S., G.J.M. Gevers, W.L.T. van Densen and J. Vijverberg 1996. Management options for a more complete utilization of the biological fish production in Sri Lankan reservoirs. Ecology of Freshwater Fish 5: 1-14. DOI: 10.1111/j.16000633.1996.tb00032.x

Pethiyagoda, R. 1991. Freshwater fishes of Sri Lanka. Wildlife Heritage Trust of Sri Lanka. Colombo, Sri Lanka, 362 pp.

Schriever, T.A. 2015. Food webs in relation to variation in the environment and species assemblage: a multivariate approach. PLoS ONE 10(4): e0122719.

https://doi.org/10.1371/journal.pone.0122719

Vijverberg, J., P.B. Amarasinghe, M.G. Ariyaratne, T. Chittapalapong, R.C. Pagulayan, E.R. Pamanian, E.I.L. Silva and L.A.J. Nagelkerke 2008. Structure of microcrustacean zooplankton communities in five south-east Asian waterbodies. Chapter 8, 153- 172 pp. In: Schiemer F., D. Simon, U.S. Amarasinghe and J. Moreau (eds), Aquatic Ecosystems and Development: Comparative Asian Perspectives, Margraf Publishers and Backhuys Publishers, Germany, Netherlands, 512 pp.

Vijverberg, J., E. Dejen, A. Getahun and L.A.J. Nagelkerke 2014. Zooplankton, fish communities and the role of planktivory in nine Ethiopian lakes. Hydrobiologia 722:45-60. DOI 10.1007/s10750-013-1674-7

Villanueva, M.C., J. Moreau, U.S. Amarasinghe and F. Schiemer 2008. Foodweb and trophic structure of two Asian reservoirs using ECOPATH with ECOSIM and ECOSPACE: a comparative study. 413-434 pp. In: Schiemer, F., D. Simon, U.S. Amarasinghe and J. Moreau (eds), Aquatic Ecosystem and Development: Comparative Asian Perspectives, Margraf Publishers and Backhuys Publishers, Germany, Netherlands, 512 pp.

Wijeyaratne, M.J.S. and W.M.D.S.K. Perera 2001. Population dynamics of potential fish species for exploitation in presently underdeveloped fisheries of some perennial reservoirs in Sri Lanka. 188-200 pp. In: S.S. De Silva (ed.), Reservoir and culture-based fisheries: Biology and management, ACIAR Publication No 98, Canberra, Australia.

Zaret, T.M 1980. Predation and freshwater communities. Yale University Press, New Haven, Connecticut. 187 pp. 